\title{
THE CORRELATION BETWEEN STUDENTS' MASTERY OF SIMPLE PAST TENSE AND THEIR ABILITY IN WRITING RECOUNT TEXT
}

\author{
By: \\ Lestari \\ Universitas Islam Ogan Komering Ilir Kayuagung \\ Lestaripark56@gmail.com \\ Fitri Novia \\ Universitas Islam Ogan Komering Ilir Kayuagung \\ novia_f@uniski.ac.id. \\ Rachmanita \\ Universitas Islam Ogan Komering Ilir Kayuagung \\ Ayuksulung2407@gmail.com
}

\begin{abstract}
The goal of this study determined a relationship between students' knowledge of the simple past tense and their ability to create a recount text in tenth-grade pupils of SMA N 07 Ogan Ilir. The study's participants were all Tenth-Grade Students at SMA N 07 Ogan Ilir. A total of 86 students were present in the population. The sample consisted of 86 students who were chosen using a total sampling technique. This investigation was carried out using correlation research. The data was administered through simple past tense mastery test and writing recount text. Pearson Product Moment correlation was employed to analyze the data.The correlation coefficient, or $r$-obtained (0.325), was found higher than $r$-table (0.176), with a $p$-value of 0.0020 .05 . It meant that learners' grasp of the simple past tense and their ability to write recount texts were related. It is possible to conclude that students' knowledge of the simple past tense has a significant impact on their ability to write recount material.
\end{abstract}

Keywords: simple past tense, writing recount text, correlation

\section{INTRODUCTION}

A set of rules developed from a language is called grammar. Most native and non-native speakers are unconcerned by the restrictions.
These guidelines, on the other hand, allowed them to connect with one another verbally and in writing without creating misleading impressions or misinterpretations. 
Many of them do not realize their mistakes in using a languange either writing or speaking. They only use the language unconciously without any concern to the language patterns. In fact we need grammar whenever we want to use a language to make a sense every detail information that we want to deliver to others.

Grammar is extremely important in students' language acquisition, particularly when learning English as a foreign language. Apsari, Saputra, and Leriandini (2019) said that students cannot deny that grammar and sentence structure encourages them to generate proper grammar to convey thoughts, concepts, or facts in their daily speaking and writing activities. Onesty and Fitrawati (2013) defined that grammar is extremely important in the teaching and learning of a language, yet it is also extremely difficult to master.

Furthermore, Uibu and Liiver (2015) noted that students should learn grammar since learning it allows them to comprehend why and how a language's rules are employed to express meaning. As a result, they have a better understanding of how language works, which they may apply in everyday interactions.

Moreover, grammar is an essential component of the teaching and learning process, as it supports language abilities, particularly writing abilities (Setyowati and Hardiastikna, 2019). Since it is one of the most crucial aspects of teaching and learning.

Everyone can efficiently exchange information by writing and this is why it is called as a means of communication. At the same time it is 
becoming important since it widely used in education and the workplace (Novia and Saptarina, 2020). Further, Betoni and Ulfaika (2020) mentioned that good writing is simply writing that is free of errors, such as grammar, punctuation, and spelling. Without the ability to express oneself in writing, students will be unable to communicate.

Furthermore, writing is taught in high schools as well as universities. According to 2013 curriculum, students in grade 10, especially, should learn about some text. Recounts, narratives, procedures, reports, and analytical expositions are among the sorts of text that students must write.

Recount text takes an important part in Senior High School. It tells about the past and attempts to reconstruct it through the retelling of events. Ginting, Rahmawati, and Purwanto (2019) declared that a recount text retells the sequences of events that occurred at a certain point in time. As a result, while pupils are writing a recount text, the past tense is employed.

Meanwhile, students must comprehend the linguistic elements employed in recount text in addition to the generic structures of recount text. One of the linguistic elements employed in the recount text is simple past. Asmiyati and Nurdiawati (2016) defined that students must write a recount text in the simple past tense if it is about something that happened in the past.

Simple past tense is to express things that occurred in the past. Things that happened in the past could have been one-time, repeated, or habitual. Fitria (2020) remarked 
that past tense depicts events that must have occurred in the past. It can be combined with either of the two aspects, perfect and progressive. Based on the preceding statements, it is possible to conclude that simple past tense is used to express an action that took place in the past.

However, students frequently struggle with writing recounts text, particularly in grammatical terms. Tuminah et al. (2021) noted that $\mathrm{m}$ (Tulak et al., 2016)any pupils make tenses errors because they don't understand the difference between regular and irregular verbs.

Moreover, Tulak, Jamiluddin Nadrun (2016) assumed at least two reasons that make the students difficult composing a recount text. Firstly, Students had ideas for what they wanted to write, but they lacked of the language to put them into a meaningful sentence. Secondly, due of their lack of grammar, leaners were unable to build a good sentence. It causes individuals to make a lot of grammatical mistakes in their work.

Thus, students' comprehension of the simple past and their ability to create recount text are related. Murdani and Mukhaiyar (2020) claimed that students with a high mastery of the simple past received a high score in writing recount texts, while students with a low mastery of the simple past received a low score in composing recount texts. It was discovered that the more proficiency students had in the simple past tense, the better their ability to produce recount text was.

\section{METHODOLOGY}

This study relied on correlation. It is a statistical test that 
assesses the consistency with which two (or more) variables or sets of data vary (Creswell, 2012).

The participants in this study were all tenth-grade students at UPT SMA N 07 Ogan Ilir. There were a total of 86 students who took part in this research. The total sampling technique was employed. Sugiyono (2017, p.140) defined that total sampling is a sampling approach that takes a representative sample of the entire population. In populations of less than 100 people, census research should be used to ensure that all members of the population are sampled, either as study subjects or as information providers.

Two different sorts of tests were used in this research. First, a simple past tense mastery test in multiple choice format. Students select one correct answer from a list of five. The author asked the students 50 questions. Second, there was a written test about recount text. Based on the specified topic, the students prepared a recount text.The students' ability to write a recount text was evaluated using a rubric.

Meanwhile, percentage analysis was used to rate the student's mastery of the simple past tense test. The association between students' grasp of the simple past tense and their ability to construct a recount paragraph was determined using Pearson productmoment correlation. To calculate the data, the SPPS program was employed.

\section{RESULT AND DISCUSSION}

The result of simple past tense showed that 16 students (19\%) were very good category, 8 students (9\%) were good category, 4 students (5\%) were 
average category and 58 students (67\%) were low category.

The result of writing recount text showed that 5 students $(6 \%)$ were very good category, 23 students (27\%) were good category, 22 students $(25 \%)$ were average category, and 36 students (42\%) were low category.

Based on the findings of Pearson Product Moment Coefficient, the correlation coefficient or $r$ obtained (0.325) was found to be greater than the $\mathrm{r}$ table $(0.2120)$ at a significant level of 0.002 , which was less than the $\mathrm{p}$ value of 0.05 . It meant that the alternative hypothesis (Ha) had been accepted while the null hypothesis (Ho) had been rejected. Finally, there was a correlation between students' ability to compose recount texts and their grasp of the simple past tense.

The students' recount text writing skill, on the other hand, influenced on their recount text writing ability. Students could construct an effective recount paragraph by grasping simple past tense. Students who had good scores about the simple past tense were able to write a recount text. It was supported by Putri, Silvianti, and Achmad (2016) who stated that students with a strong grasp of the simple past scored well in recount writing, while those with a weak grasp of the simple past scored poorly. Grammar mastery has a big impact and plays a key function in writing skills since it assists students in becoming more correct and understandable to readers (Khairunisa, Nadrun, and Rachmania 2018) 


\section{CONCLUSION}

Based on the analysis data, the obtained $r$ was higher than the $r$ table, according to the results. The alternative hypothesis (Ha) was accepted and the null hypothesis (Ho) was rejected since the $\mathrm{p}$ value was less than 0.05 . It was able to conclude that students' grasp of the simple past tense and their ability to create recount text had a substantial relationship.

\section{REFERENCES}

Apsari, Y., Saputra, I. A., \& Leriandini, G. (2019). Students' perception of snowball throwing in teaching grammar. PROJECT (Professional Journal of English Education), 2(2), 152. https://doi.org/10.22460/project. v2i2.p152-158

Asmiyati, \& Nurdiawati, D. (2016). An error analysis of simple past tense used in writing recount text. Dialektika, 4(1), 71-84. Betoni, T., \& Ulfaika, R. (2020). The correlation between students' grammatical mastery and students' writing achievement at XI Grade students of SMAN 1 Tarakan academic year 2019/2020. Borneo Journal of English Language Education, 2(1), 42-55.

Creswell, J. W. (2012). Educational research: Planning, conducting, and evaluating quantitative and qualitative research (Fourth). Pearson Education, Inc.

Fitria, T. N. (2020). Error analysis in using Simple Past Tense found in students' writing of Recount Text. Ahmad Dahlan Journal of English Studies, 7(1), 39. https://doi.org/10.26555/adjes.v7 i1. 12238 
Ginting, H. K. B., Rahmawati, \& Purwanto, P. (2019). Error analysis on using simple past tense in writing recount text at the eighth grade of SMP Bina Bersaudara 1 Medan. Jurnal Edulingua, 6(1), 13-17.

Khairunisa, A., Nadrun, \& Rachmania. (2018). The correlation between students' grammar mastery and writing skill. E-Journal of English Language Teaching Society, 6(3), 1-11.

Murdani, O., \& Mukhaiyar. (2020). The correlation between students' mastery in Simple Past Tense with the ability of writing Recount Text. Journal of English Language Teaching, 9(4), 4-7. https://doi.org/10.24036/jelt.v9i4 .117904
Novia, F., \& Saptarina, E. (2020). Process Writing Approach (PWA): The correlation between students writing attitude and writing achievement. 4th Sriwijaya University Learning and Education International Conference (SULE-IC 2020) Process, 513, 331-336. https://doi.org/10.2991/assehr.k. 201230.127

Onesty, R., \& Fitrawati. (2013). Using word by word games in teaching grammar for junior high school students. Journal of English LanguageTeaching, 1(2), 10-19.

Putri, Z., Silvianti, T. M., \& Achmad, D. (2016). The Correlation Between Grammar Mastery and Writing Ability. Proceedings of the First Reciprocal Graduate Research Symposium between 
The Correlation between Students' Mastery of Simple Past Tense and Their Ability in Writing Recount Text

University Pendidikan Sultan

Idris and Syiah Kuala

University, 217-222.

http://repository.uinjkt.ac.id/dspa

ce/bitstream/123456789/25290/3

/RENI SEPTIANI-FITK.pdf

Setyowati, L., \& Hardiastikna, D. D.

(2019). The correlation between

grammar and writing

achievement of EFL sophomore

students at STKIP PGRI

Pasuruan, Indonesia. Linguista:

Jurnal Ilmiah Bahasa, Sastra,

Dan Pembelajarannya, 3(1), 31.

https://doi.org/10.25273/linguist

a.v3i1.4542

Sugiyono. (2017). Metode penelitian

kuantitatif, kualitatif, dan $R \& D$.

Alfabeta.

Tulak, L., Jamiluddin, \& Nadrun.

(2016). Correlation between

mastery of simple past tense and

the ability in writing recount text at the tenth grade. Journal of

English Language Teaching

Society (ELTS), 4(1), 2331-

1841.

https://media.neliti.com/media/p

ublications/242322-correlation-

between-

Tuminah, Nopinawati, Selong, Y., \& Faridha, N. (2021). Analysis of error using Simple Past Tense on Recount Text Class VIII B students of SMP Pelita Ngabang in the academic year 2019/2020

Landak district. Udayana

Journal of Social Sciences and Humanities (UJoSSH), 5(1), 28. https://doi.org/10.24843/ujossh.2 021.v05.i01.p04

Uibu, K., \& Liiver, M. (2015).

Students' grammar mistakes and effective teaching strategies.

International Journal of

Teaching and Education, III(1), 
Lestari, Fitri Novia, Rachmanita

70-87.

https://doi.org/10.20472/te.2015.

3.1 .006 